\title{
A Sensitive PCR-Based Method for Somatic Mutations Enrichment and Screening [Corrigendum]
}

Xiong Y, Tang H. Cancer Manag Res. 2021;13:8099-8107. The authors apologize for this error.

The authors have advised there is an error in Figure 2 on page 8101 . The legend "EGFR G12D/G13D" should read "KRAS G12D/G13D".

\section{Publish your work in this journal}

Cancer Management and Research is an international, peer-reviewed open access journal focusing on cancer research and the optimal use of preventative and integrated treatment interventions to achieve improved outcomes, enhanced survival and quality of life for the cancer patient
The manuscript management system is completely online and includes a very quick and fair peer-review system, which is all easy to use. Visit http://www.dovepress.com/testimonials.php to read real quotes from published authors. 